\title{
TESTAMENTO DE UN SUEÑO
}

\section{Testament to a dream}

\section{Daniel Hernández-Salazar}

Pareciera que Guatemala está condenada a un destino controlado por la élite económica. El juicio por Genocidio al General Efraín Ríos Montt y los acuerdos de paz parecen ahora espejismos de sueños de democracia. Ese proceso fue un hito en nuestra historia reciente. Pareció un rayo de luz y esperanza que nos hizo creer que podiamos construir un futuro distinto. Poco nos duró la alegría. Era obvio. Fuimos ilusos. Poco tiempo después del veredicto de culpable, Sury, su hija amenazó veladamente, advirtiendo a los verdaderos actores que, si no lo ayudaban, ellos serían señalados. Después de él caerían ellos los verdaderos culpables, los que dieron las órdenes. «Detrás de mi Papi caerá mucha gente» dijo a los medios de prensa. ¿A quiénes iba dirigido ese mensaje? A los de siempre, los criollos, miembros de la oligarquía, y a sus sirvientes militares que, a toda costa reprimieron y eliminaron a los que llamaron uel enemigo interno", aplicando ferozmente una doctrina de seguridad nacional, bajo la cual implementaron planes de campaña militar de «tierra arrasada». Aniquilaron la resistencia de la población y borraron del mapa a comunidades enteras, cometiendo las peores atrocidades conocidas, durante el conflicto armado interno que asoló este país más de tres décadas. Esos criollos son los herederos de los conquistadores españoles, quienes desde la independencia de España, han manejado los hilos y decidido lo que puede y lo que no puede ocurrir en Guatemala. Ellos son los que este año celebran el bicentenario de esa emancipación política, que materializó y consolidó su dominio y explotación total de este territorio.

Luego del asesinato de Monseñor Juan Gerardi en abril de 1998, Guatemala comenzó otra caída vertiginosa hacia las obscuridades de la impunidad y la injusticia. Esta se vio acelerada a partir del claro veredicto de culpabilidad por Genocidio, dictado en contra del fanático y simbólico militar por la jueza Jazmín Barrios el 10 de mayo de 2013. Entonces, esas fuerzas que gobiernan tras bambalinas, movieron influencias, amenazaron y presionaron hasta lograr con base en formalismos legales, que la Corte de Constitucionalidad ordenara retrotraer el juicio hasta el inicio. Todo con la esperanza de que Ríos Montt muriera antes de ser encontrado culpable de nuevo, lo cual sucedió en 2018 , echando un ominoso manto de impunidad sobre lo ocurrido y obstaculizando de nuevo la posibilidad de sacar a este país del letargo democrático en que lo han mantenido para proteger sus intereses económicos como clase dominante.

Las imágenes que incluí en este portafolio resumen de una forma simbólica lo que ese proceso fue y representó para la historia de este país y su jurisprudencia. Viudas, campesinos, fiscales, autoridades indigenas, comunidad internacional acompañante, y finalmente la prensa como «los ojos del mundo» están representados. Estas fotografías son un testamento y mi homenaje a los protagonistas de la búsqueda de justicia por la barbarie sobrevivida en nuestro país.

Guatemala, 24 de mayo de 2021.

Cómo citar / How to cite: Hernández-Salazar, Daniel (2021). "Testamento de un sueño». Papeles del CEIC, vol. 2021/2, papel 253, 1-11. (http://doi.org/10.1387/ pceic.22927)

ISSN 1695-6494 / CC 2021 UPV/EHU 


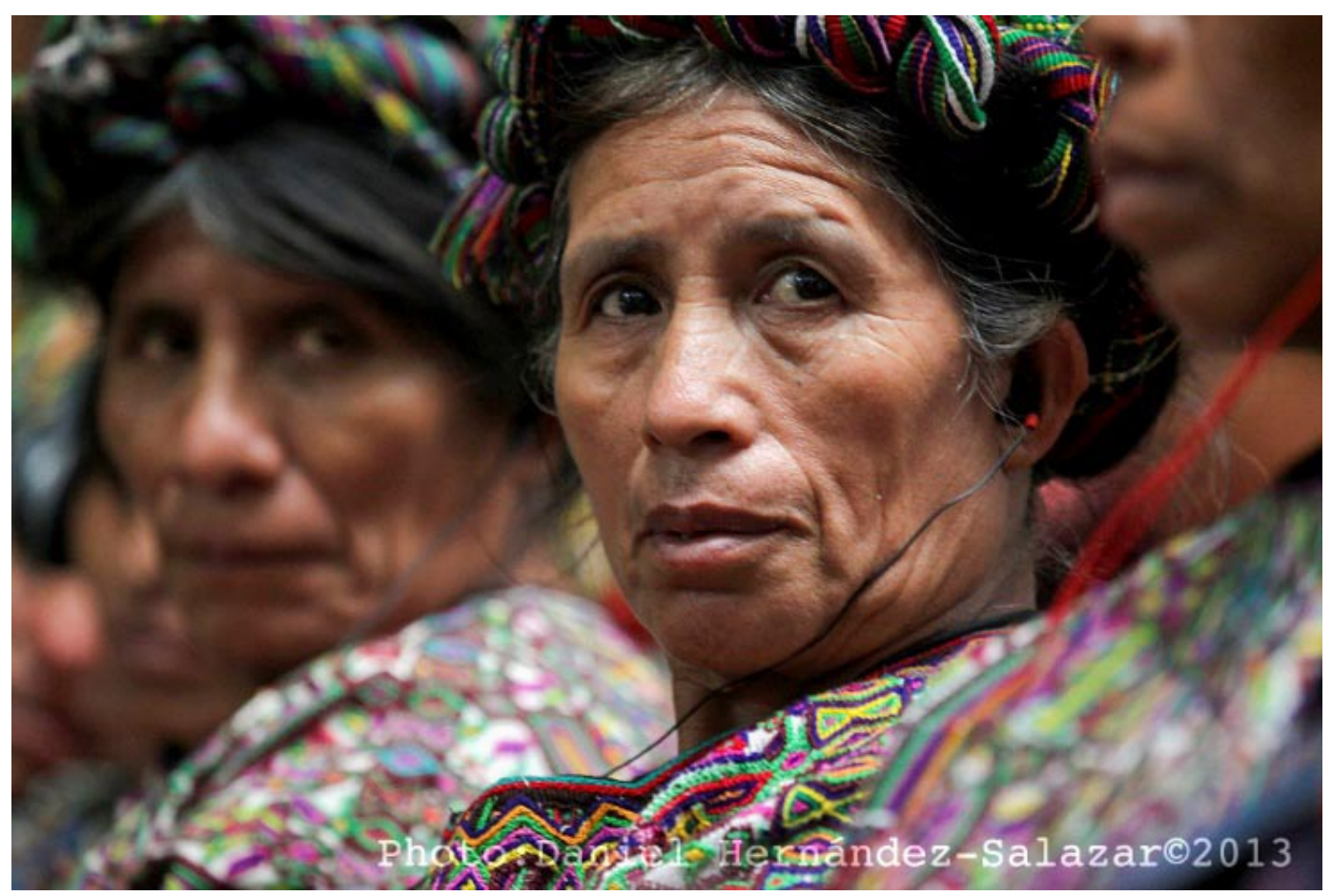

Imagen 1

Mujeres de la región Ixil, probablemente familiares de víctimas de la violencia ejercida por el régimen de Ríos Montt

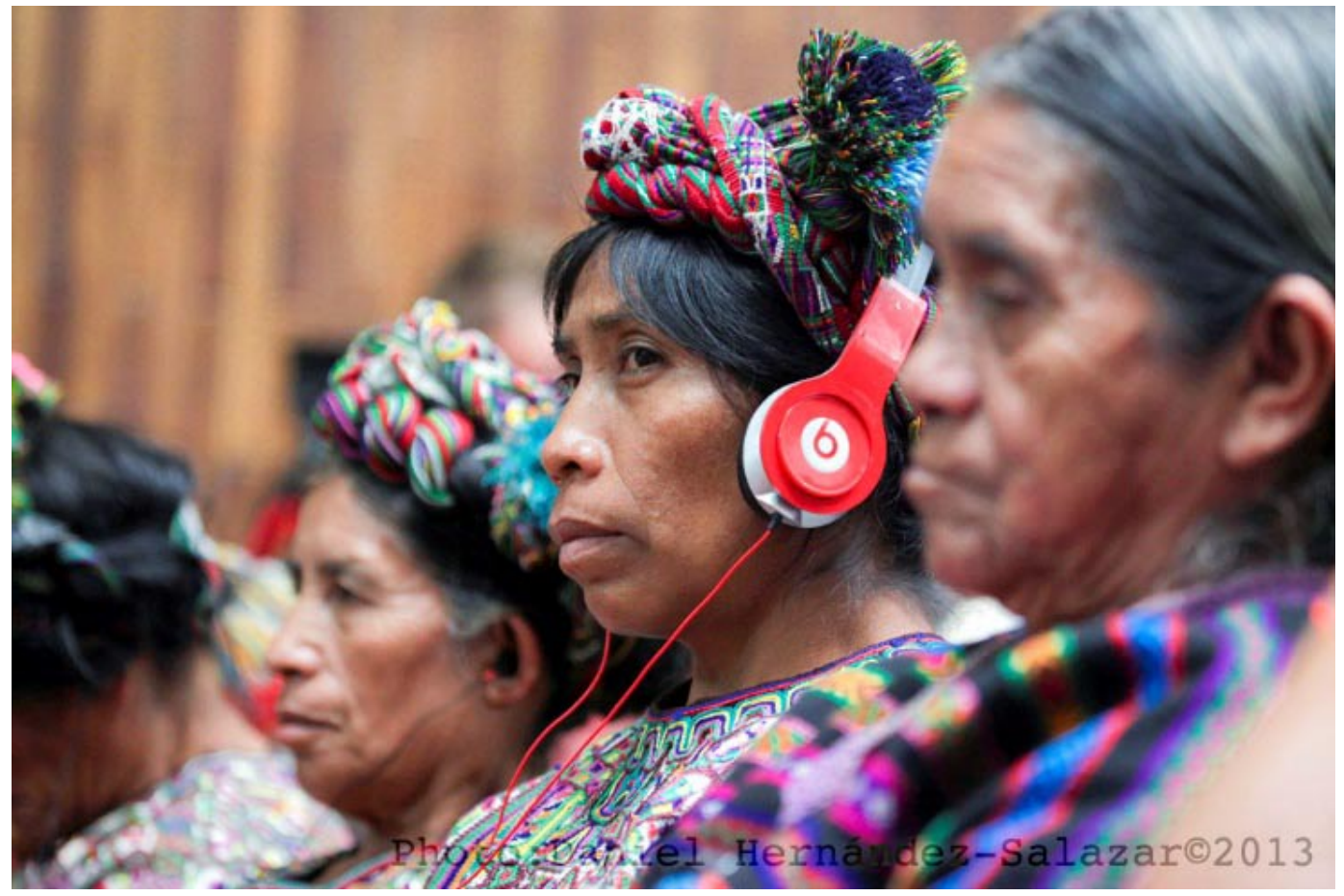

Imagen 2

Mujeres de la región IXIL del Departamento de El Quiche escuchan la traducción de una audiencia del juicio 


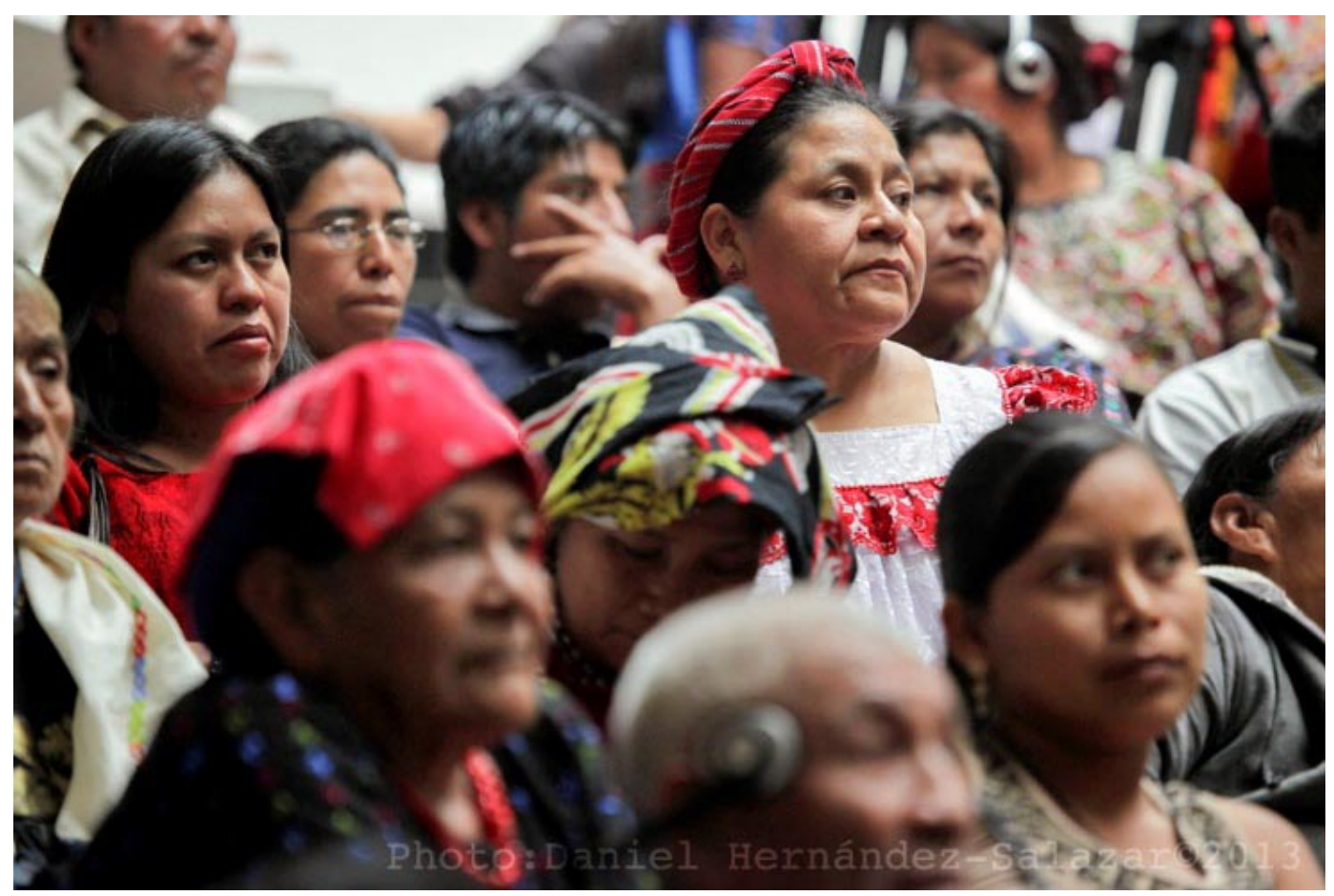

Imagen 3

Rigoberta Menchú Tum, Premio Nóbel de la Paz 1992, escucha una audiencia del juicio en contra del General Ríos Montt, rodeada de mujeres indigenas

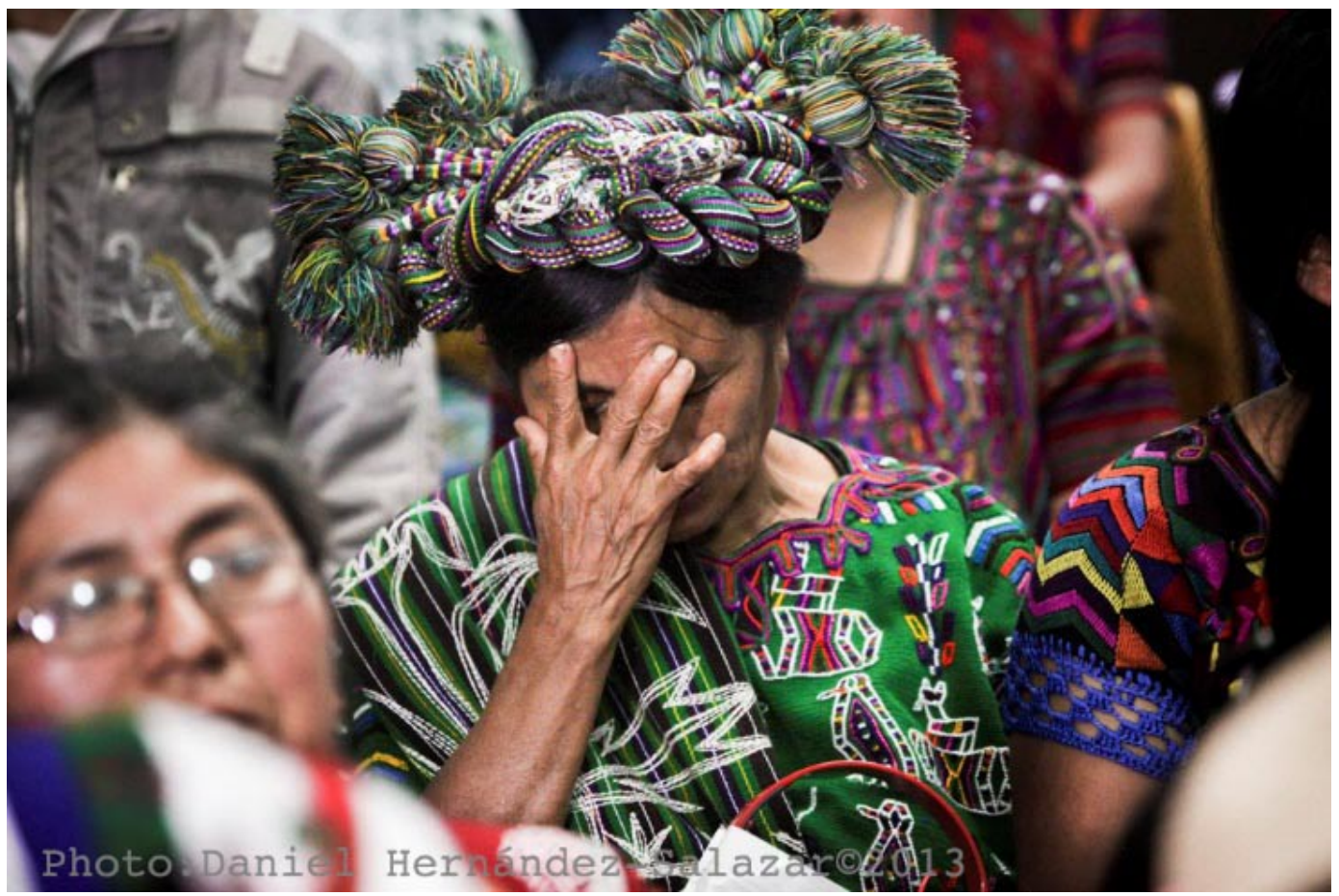

Imagen 4

Una mujer sucumbe al escuchar los testimonios de otras mujeres víctimas de la violencia, durante una audiencia del juicio por Genocidio en contra del General Ríos Montt 


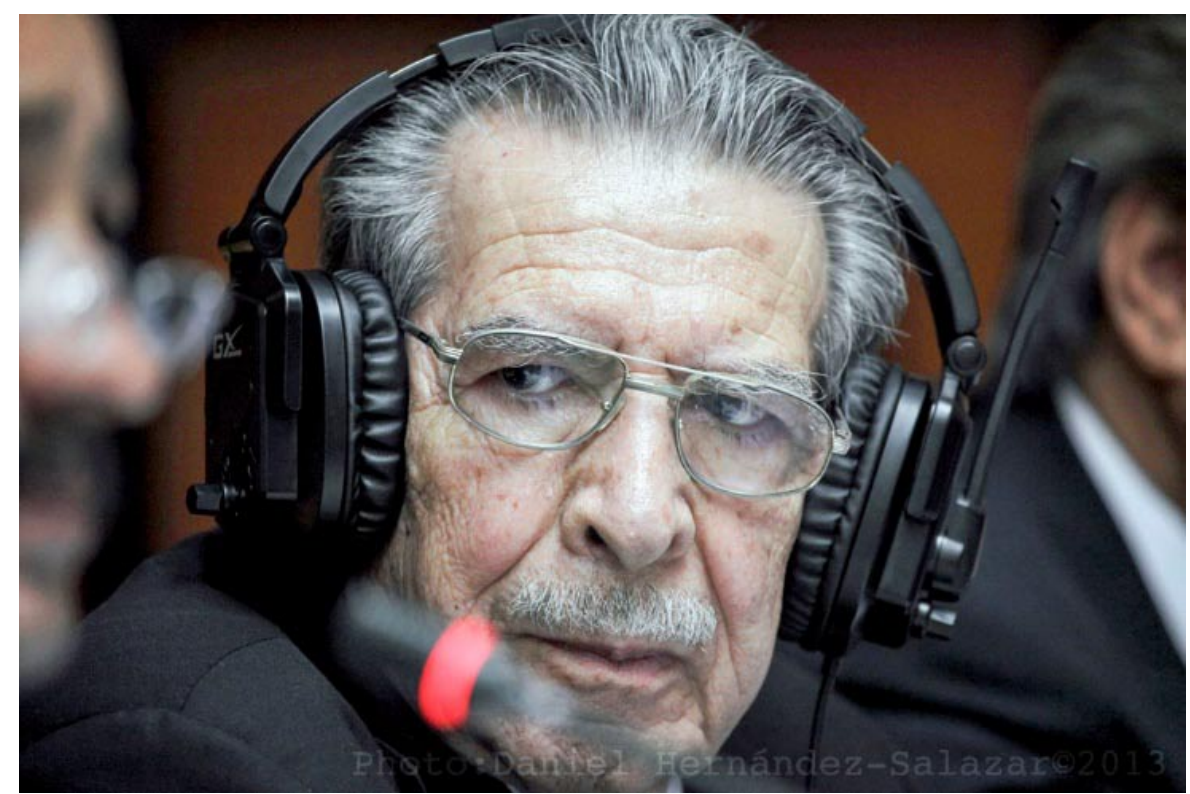

Imagen 5

El General Efraín Ríos Montt observa con intensidad durante una de las audiencias del juicio en su contra

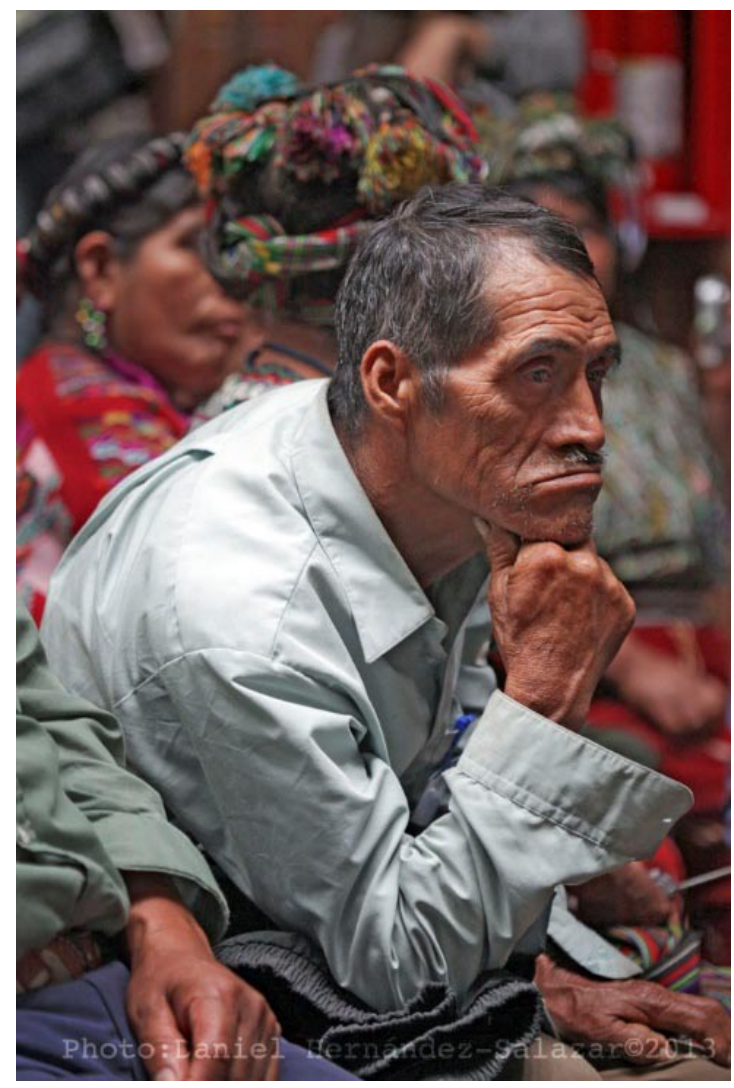

Imagen 6

Campesino de la región Maya Ixil escucha atentamente una de las audiencias del juicio contra el General Ríos Montt 


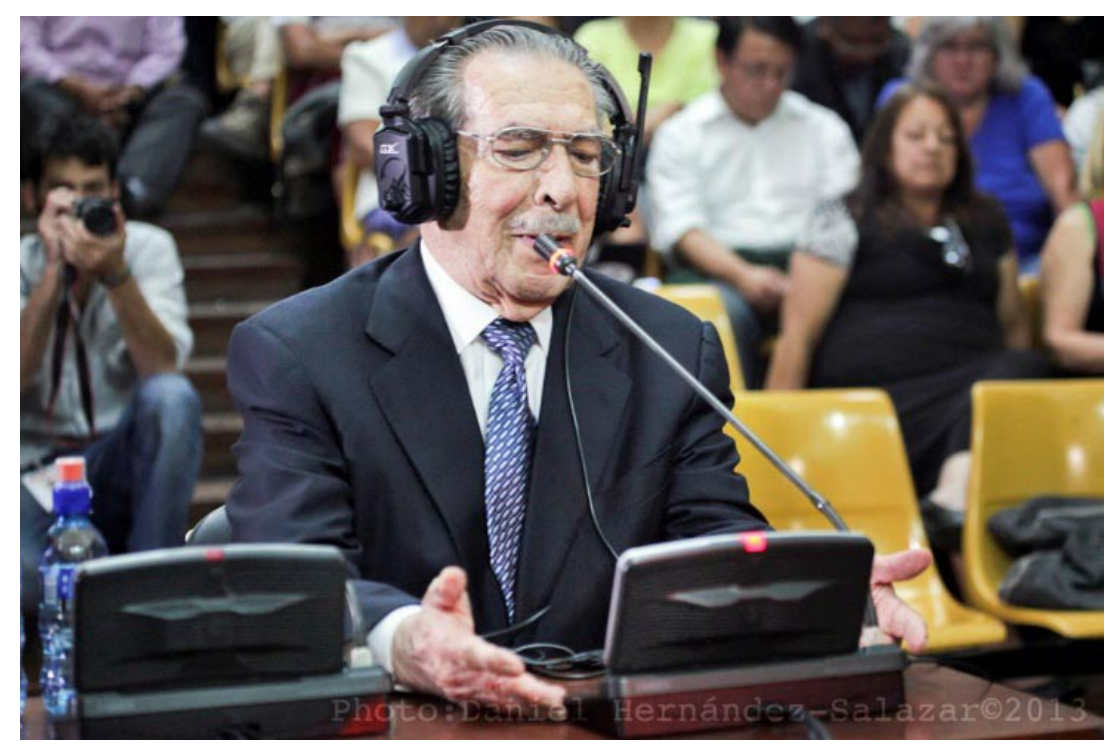

Imagen 7

El General Ríos Montt da su versión de los hechos, negando tener responsabilidad sobre aquellos sobre los cuales se le acusó de Genocidio. Sin embargo, en varias oportunidades dijo cuando era Jefe de Estado, que él estaba en control y que si no estaba enterado de todo lo que sucedía en el país, entonces para qué estaba allí, insinuando que él siempre tuvo conocimiento y control absoluto de todo lo que sucedía

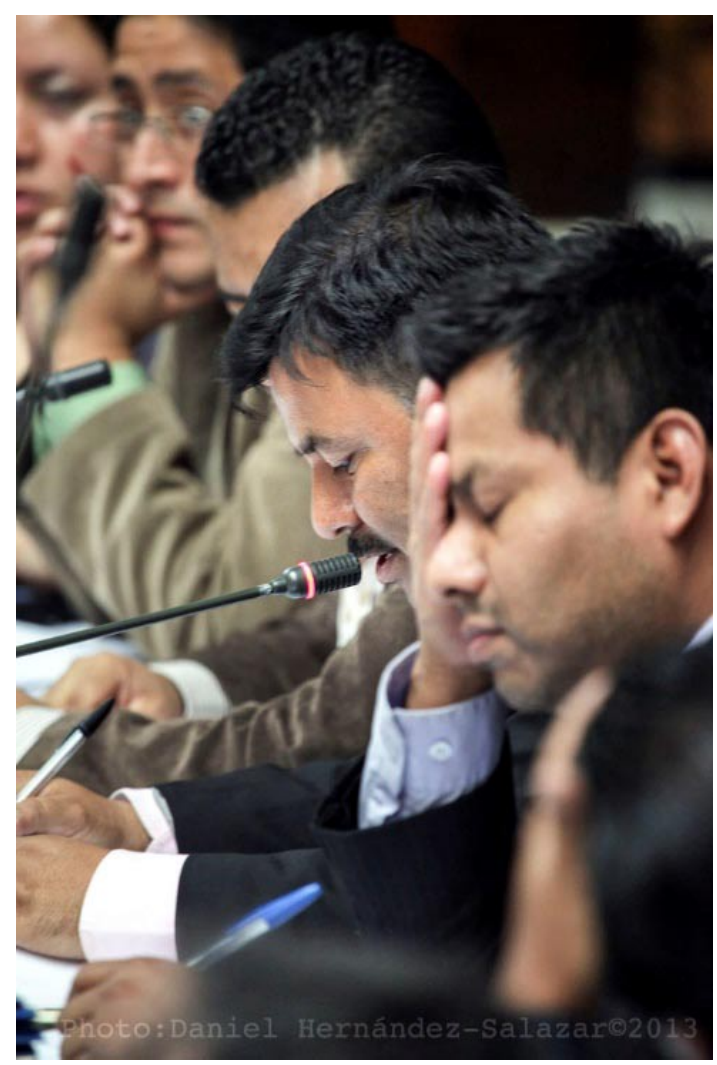

Imagen 8

Los fiscales y los querellantes adhesivos en el juicio pasaron momentos difíciles para probar la acusación en contra del General Ríos Montt 


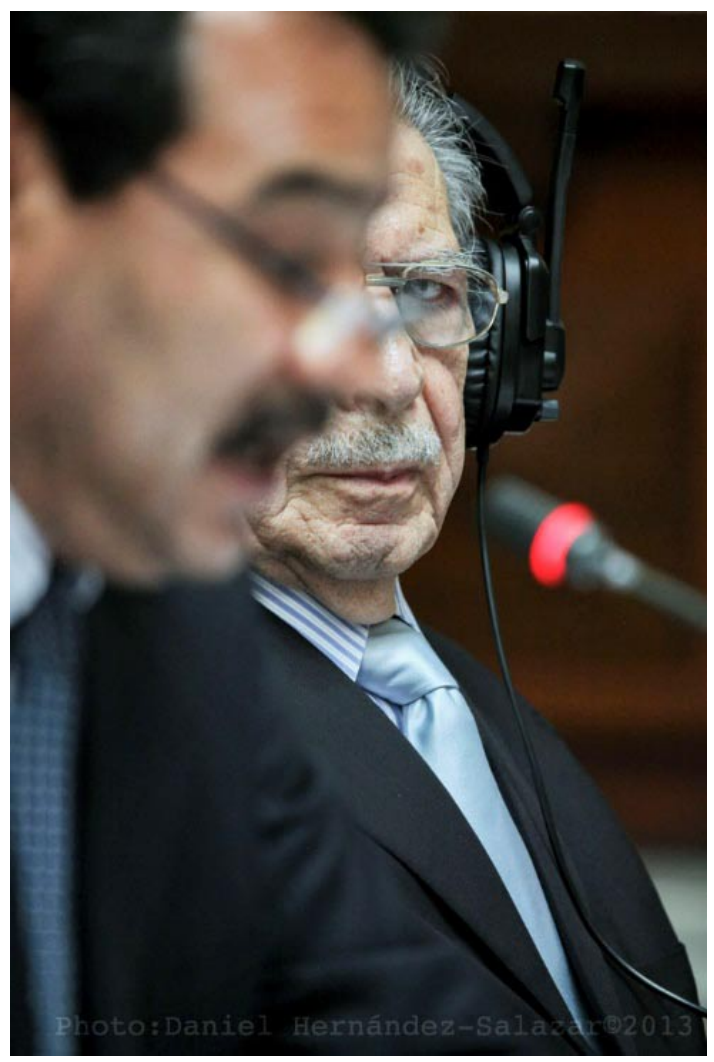

Imagen 9

Por momentos, la mirada de Ríos Montt revelaba su actitud y creencias

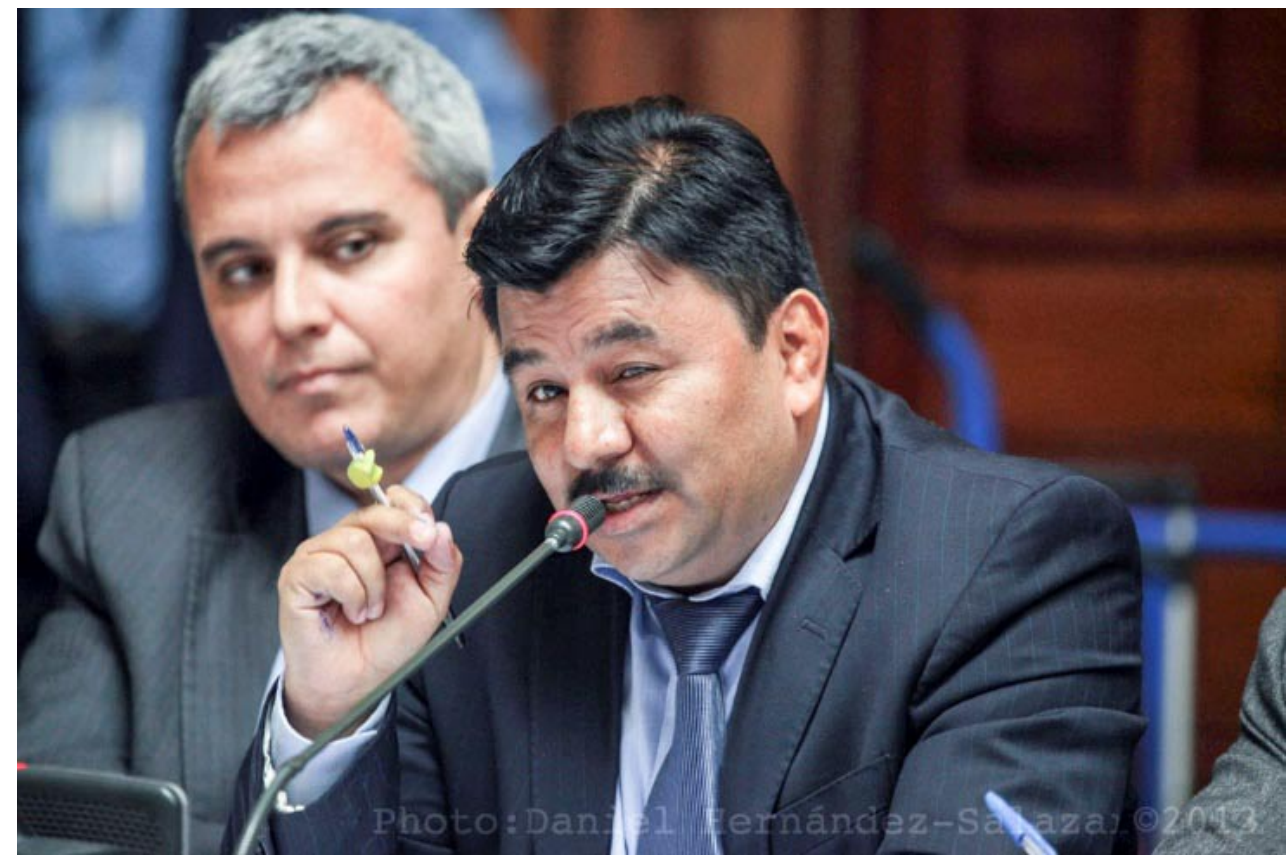

Imagen 10

El Abogado Édgar Pérez, querellante adhesivo en el proceso por Genocidio contra el General Ríos Montt, argumenta con precisión durante una de las audiencias 


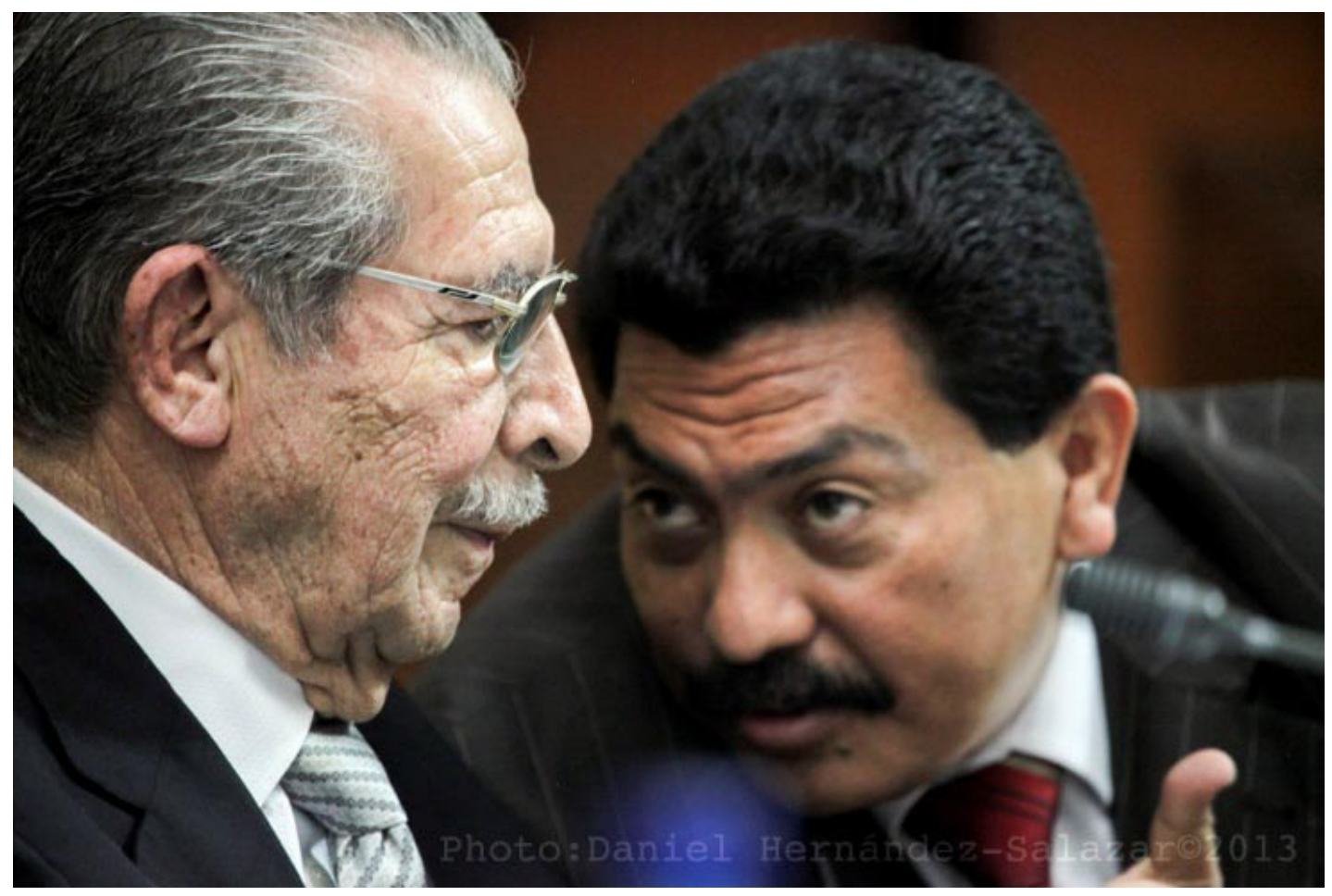

Imagen 11

El Abogado Francisco García Gudiel, defensor del General Ríos Montt, conversa con él durante una de las audiencias. García Gudiel fue capturado recientemente acusado de «lavado de activos»

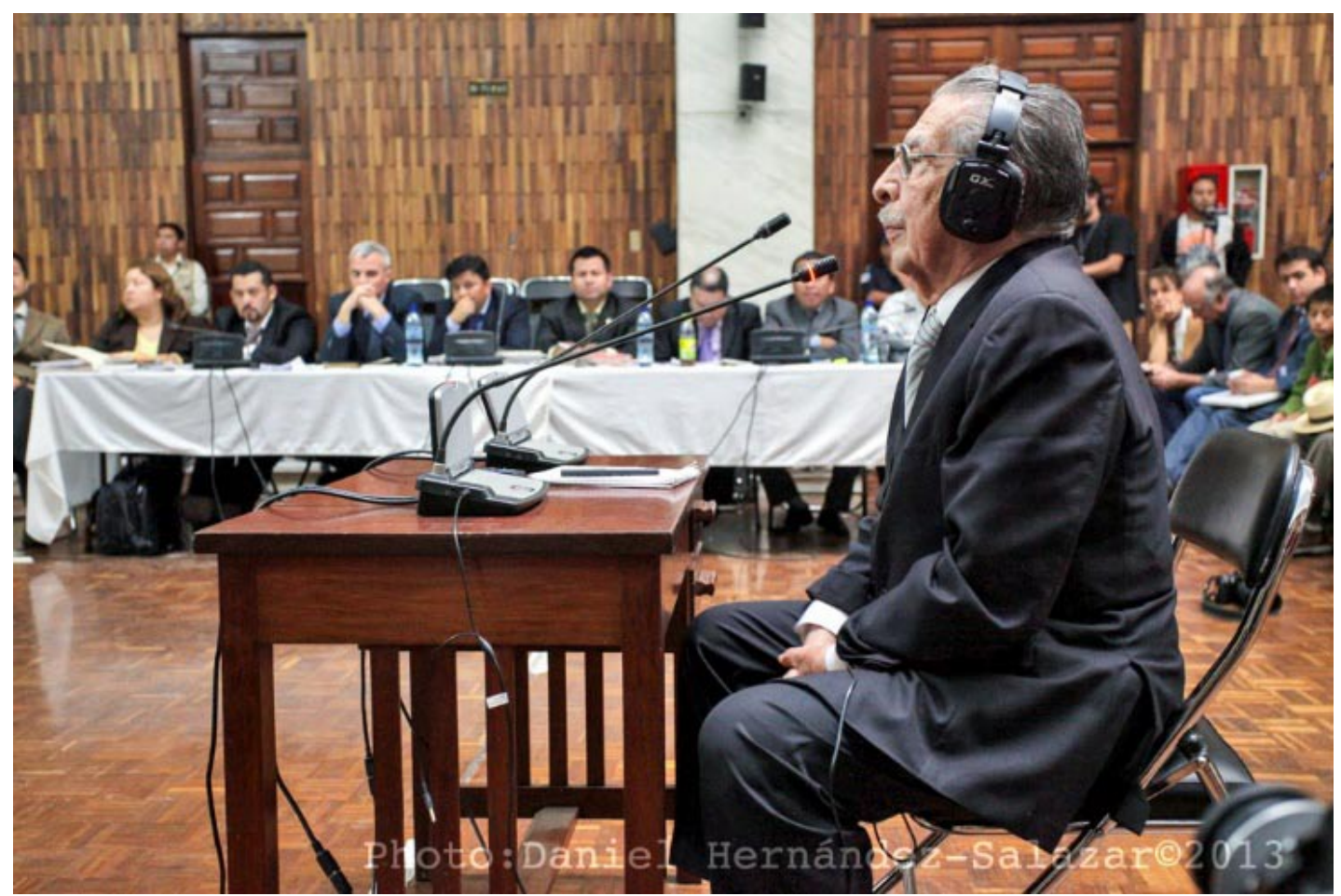

Imagen 12

El General Ríos Montt da su última declaración en el juicio en su contra por Genocidio 


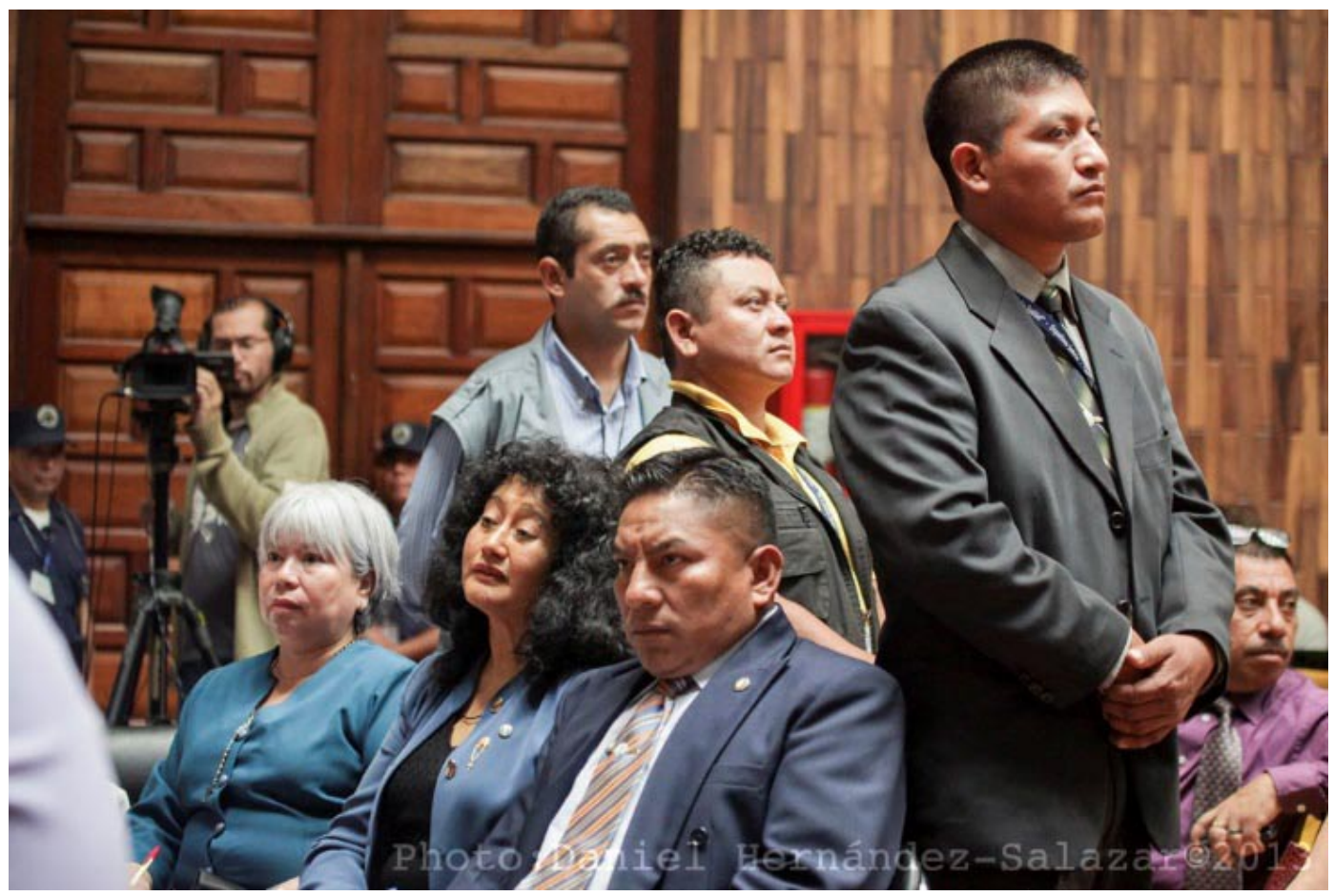

Imagen 13

Los miembros del Tribunal Primero A de Mayor Riesgo: Patricia Escobar, Pablo Xitumul y Jazmín Barrios quien lo presidió, observan un video como parte de las evidencias presentadas durante el proceso. Era notoria la presencia de su seguridad personal dada la crispación que el proceso provocó

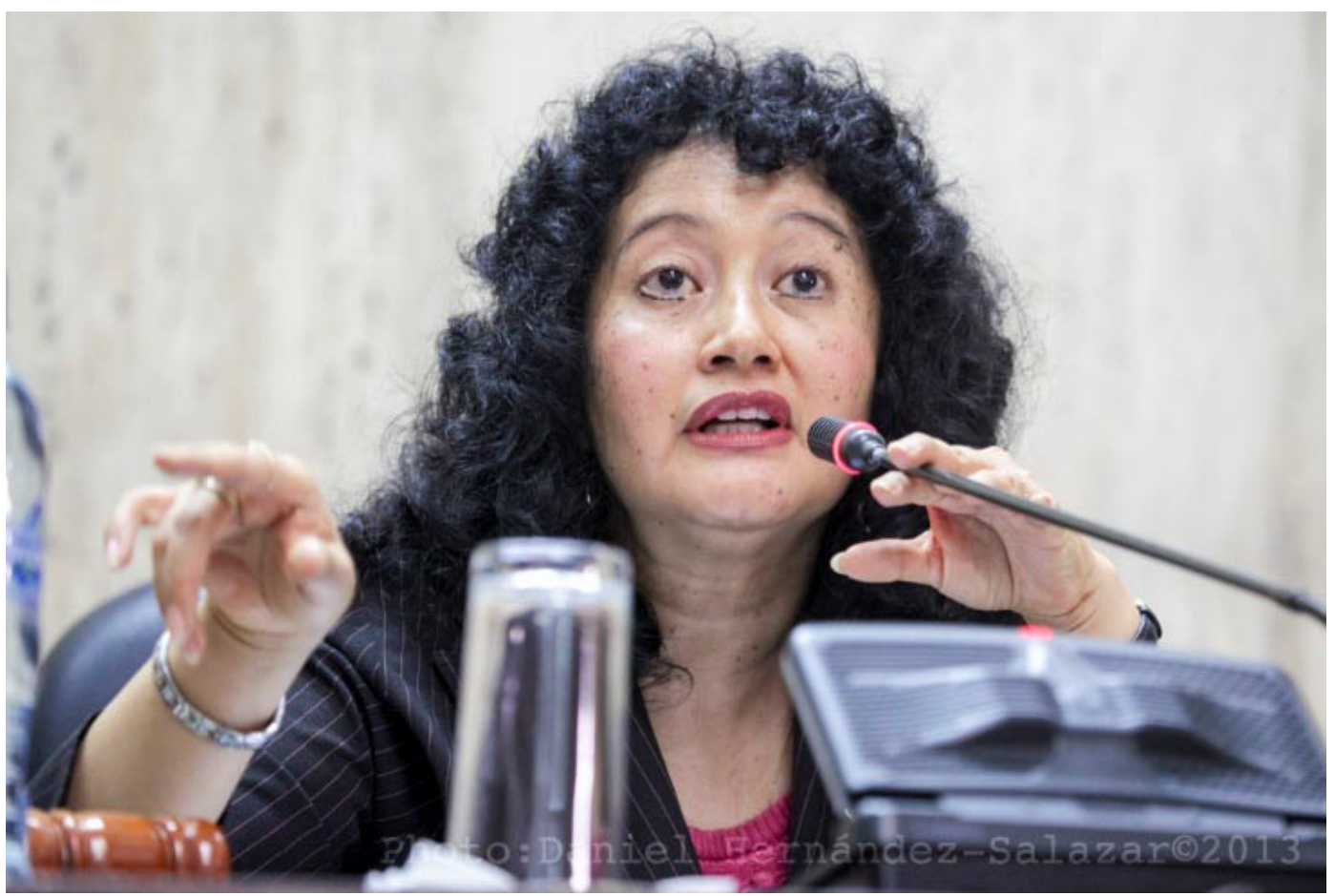

Imagen 14

La Jueza Presidenta del Tribunal Jazmín Barrios 


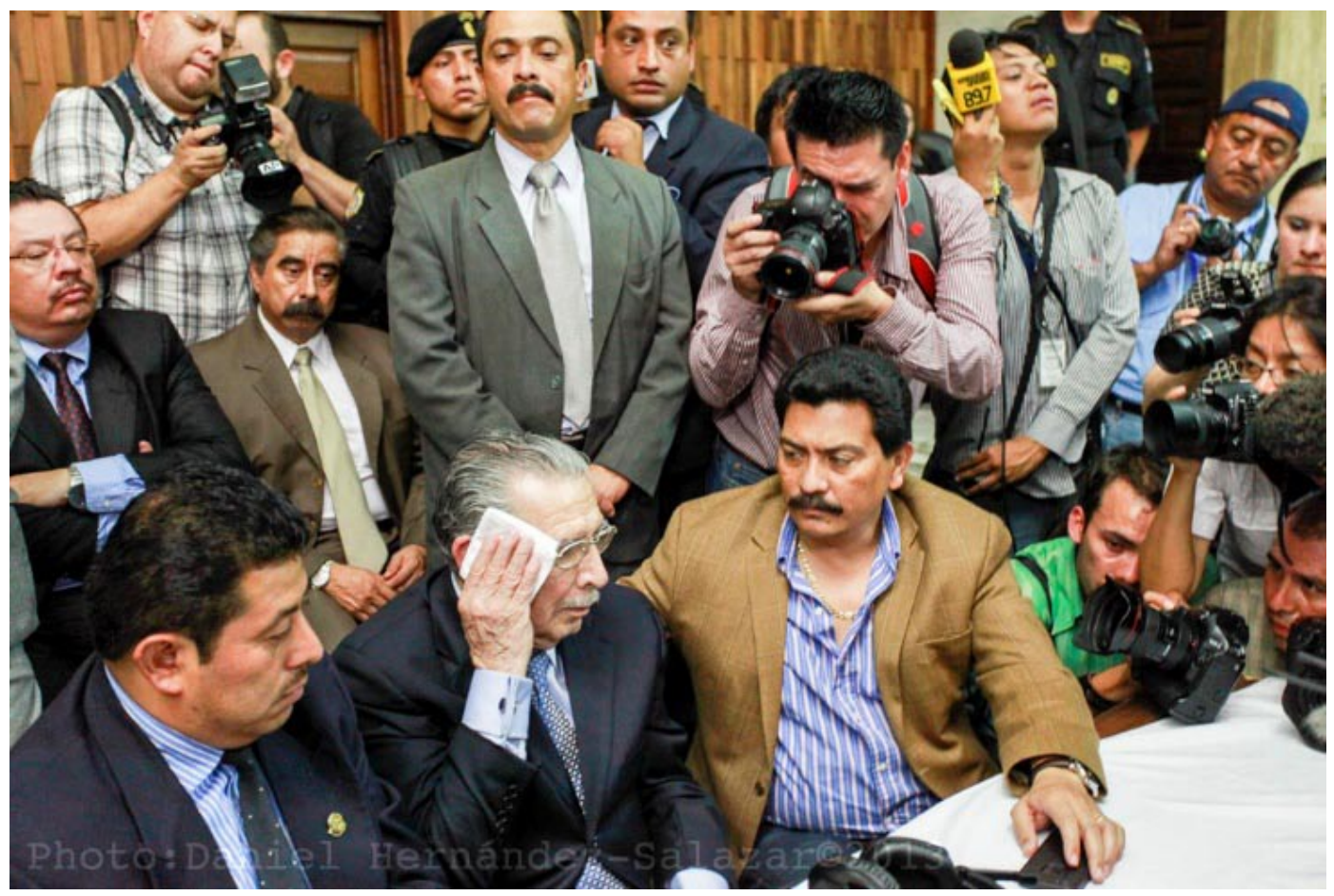

Imagen 15

El General Ríos Montt y sus abogados en el momento de escuchar la sentencia de culpabilidad por el delito de Genocidio y faltas contra Deberes de Humanidad en el juicio en su contra

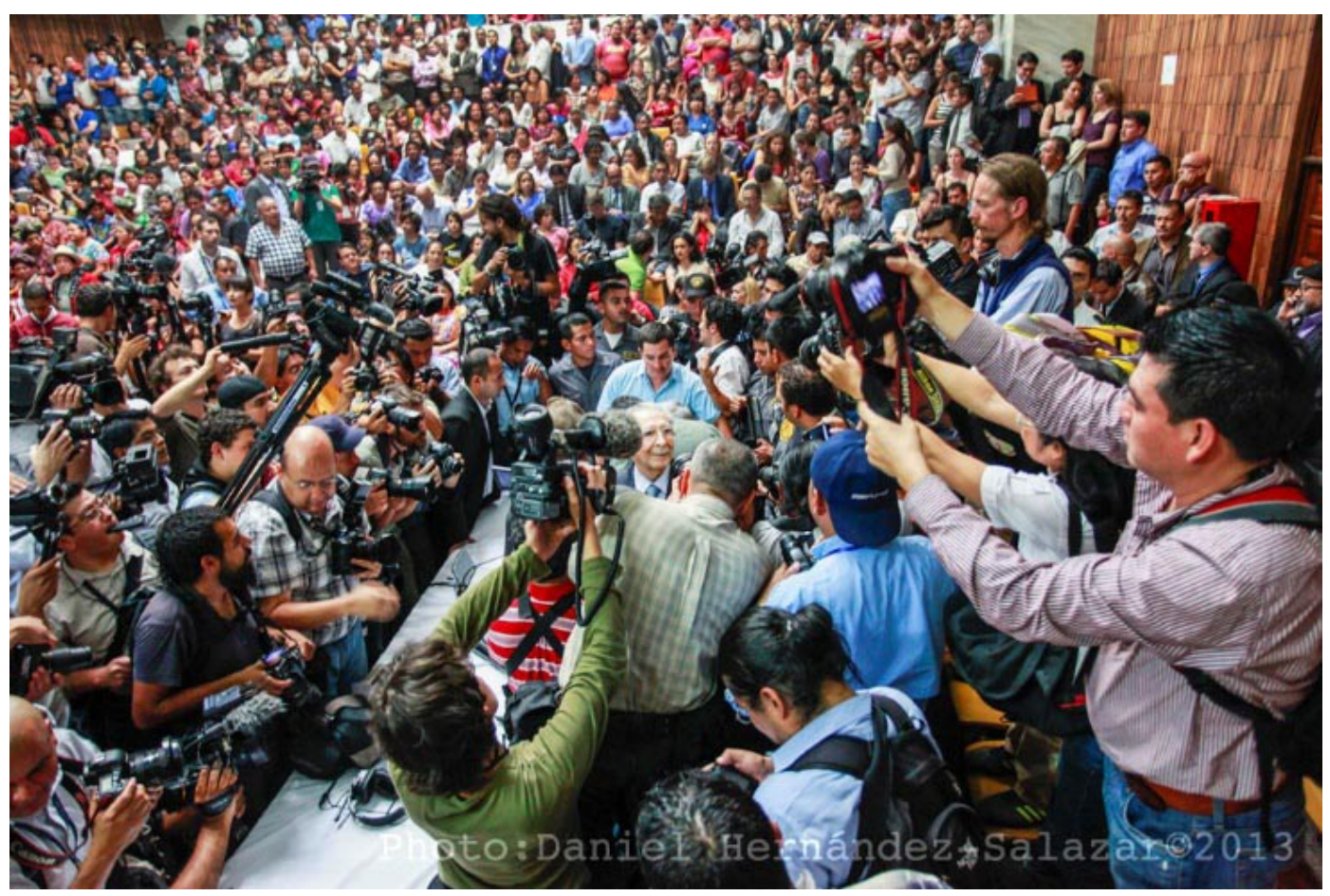

Imagen 16

El General Ríos Montt rodeado por periodistas minutos después de escuchar la sentencia dictada en su contra 


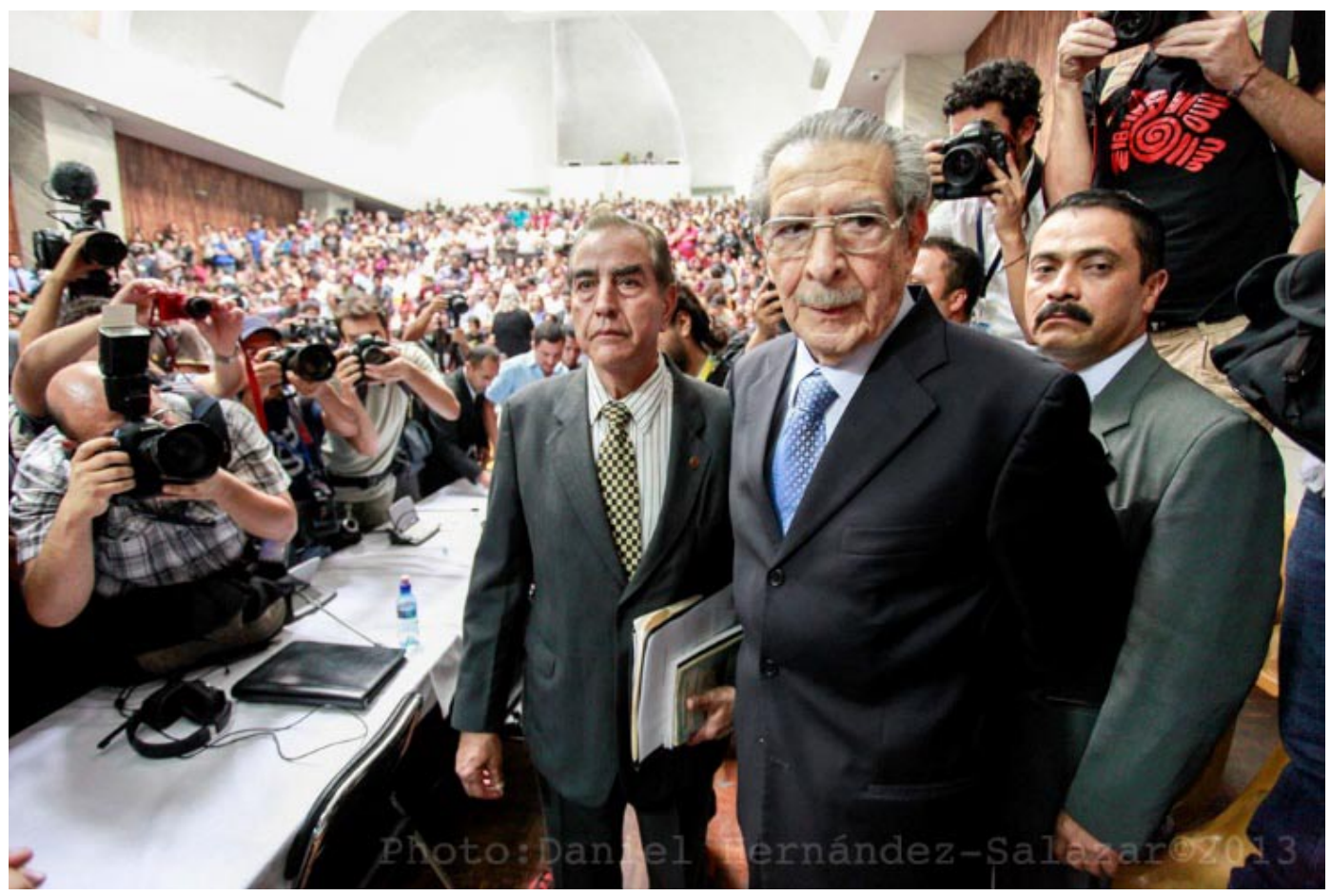

Imagen 17

El General Ríos Montt, uno de sus abogados defensores y un guardaespaldas lucen semblantes tensos después de escuchar la sentencia donde se le encontró culpable de Genocidio

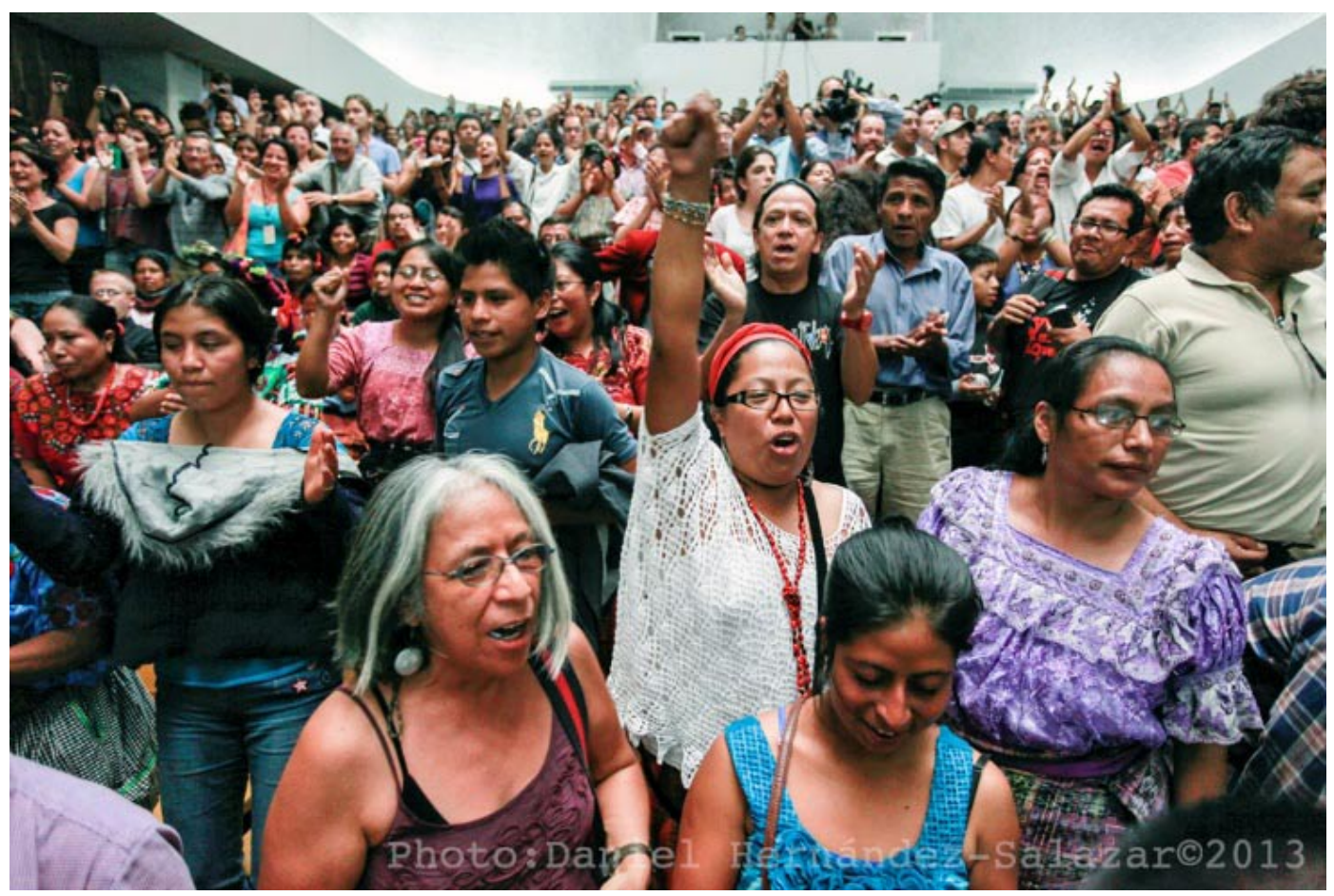

Imagen 18

El público asistente se regocija al escuchar la sentencia de culpabilidad dictada en contra del General Ríos Montt 


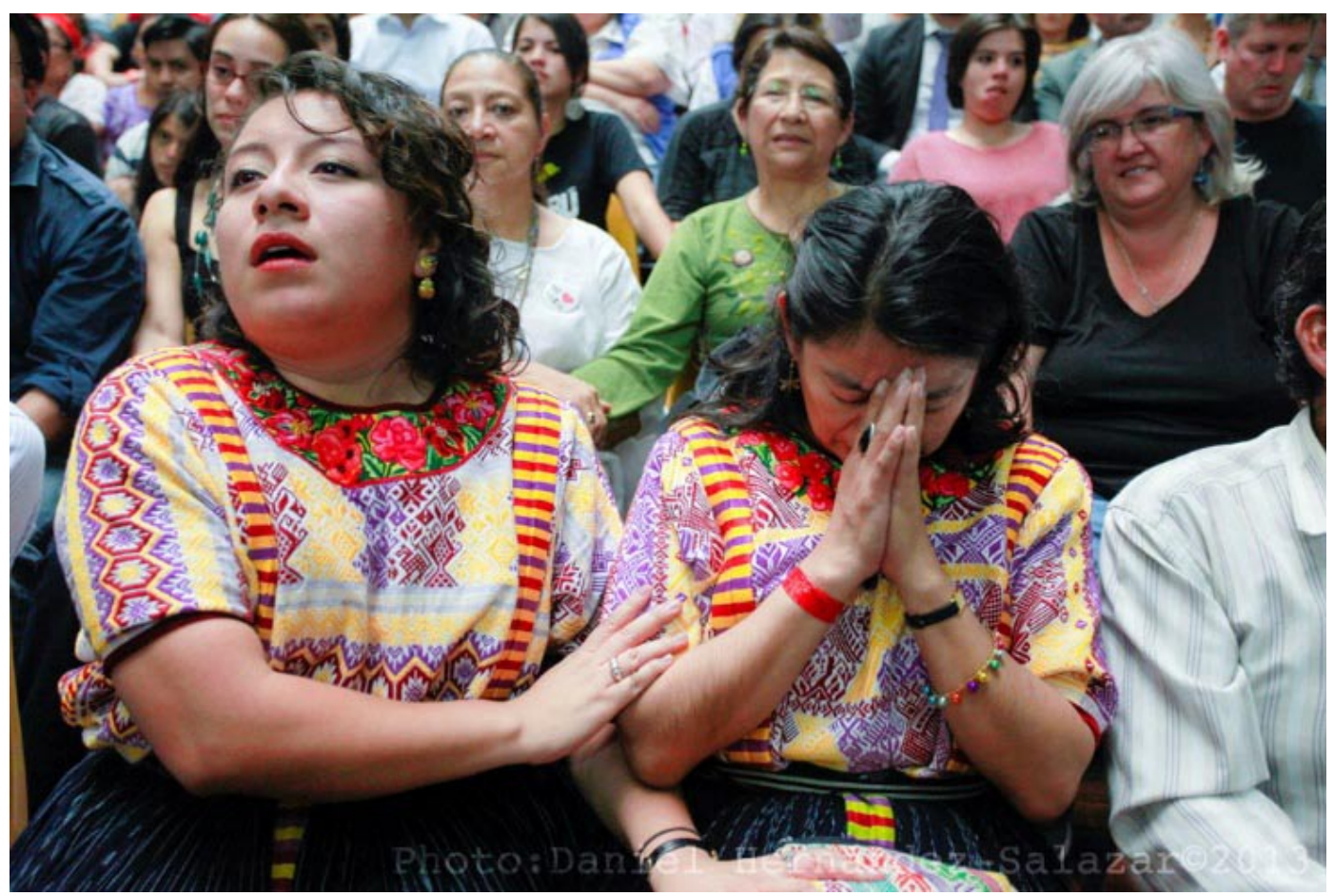

Imagen 19

María Aguilar Velázquez consuela a su madre la antropóloga Irma Alicia Velázquez Nimatuj quien rompe en llanto de la emoción al escuchar la sentencia en contra del General Ríos Montt

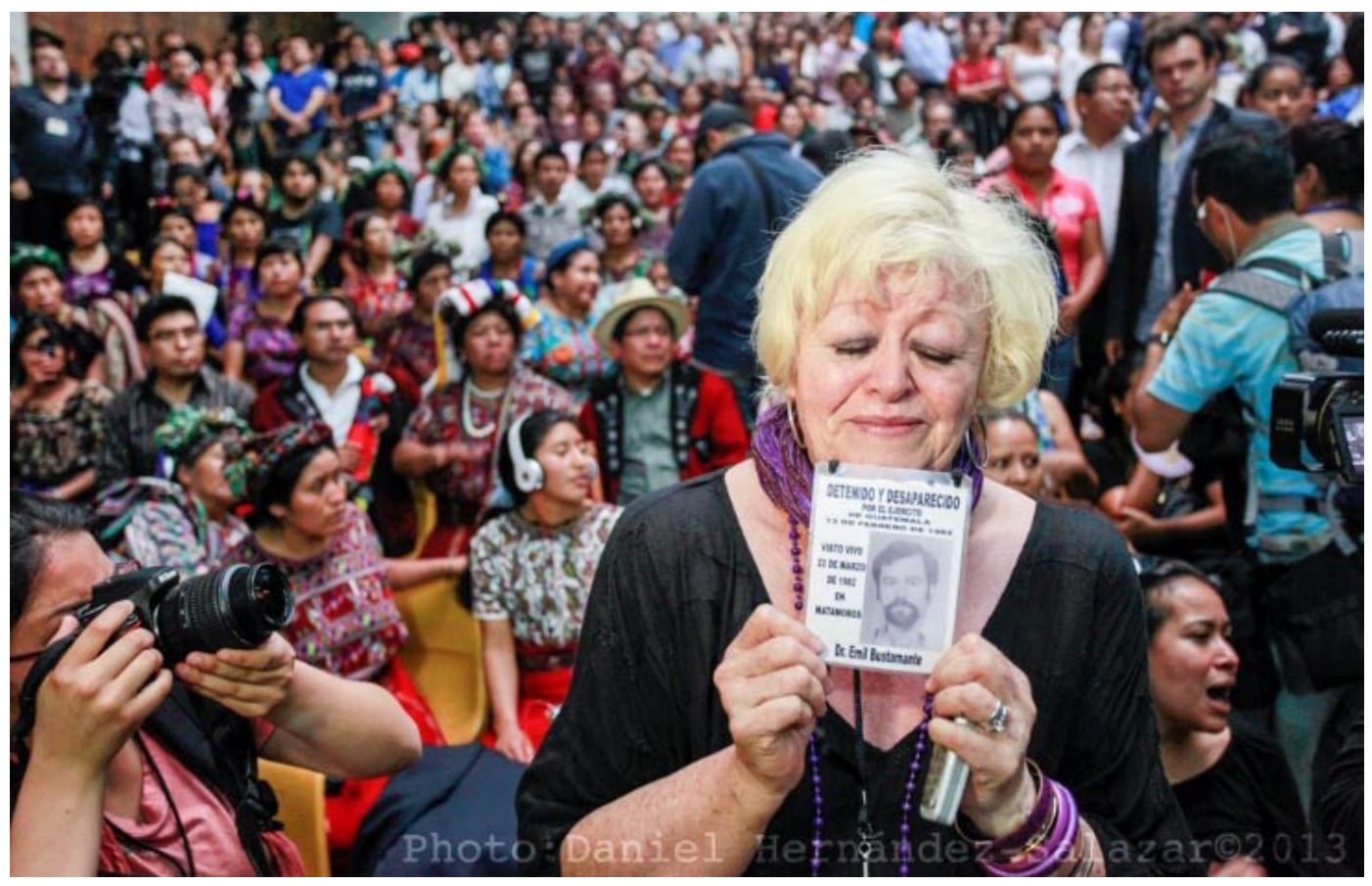

Imagen 20

Marylena Bustamante sostiene la foto de su desaparecido hermano Emil y parece flotar al escuchar la sentencia en contra del General. Emil Bustamante fue capturado durante el régimen de Ríos Montt y nunca se supo de su paradero 